\title{
SUBSTITUTION OF SYNTHETIC HORMONES WITH ORGANIC MATERIALS ON THE GROWTH OF ORCHID PLANTS (Phalaenopsis amabilis) AS A GROWTH REGULATORY SUBSTANCE IN VITRO
}

\author{
Kevin Febrianus Moda ${ }^{1}$, Dimas Ridho Irvansah ${ }^{1}$, Novita Sari ${ }^{2}$, Febriana Dwi Wahyuni ${ }^{1}$ \\ ${ }^{1)}$ Biotechnology Study Program, Faculty of Health Sciences, Universitas Esa Unggul, Jakarta, Indonesia \\ ${ }^{2)}$ Pharmacy Study Program, Faculty of Health Sciences, Universitas Esa Unggul, Jakarta, Indonesia. \\ febriana@esaunggul.ac.id
}

\begin{abstract}
In Indonesia, the agribusiness sector has begun to expand due to the increase in entrepreneurship of orchid plants. Several genera and species of orchid plants are promising to be traded as ornamental plants, one of which is the moon orchid (Phalaenopsis amabilis). However, the limited number of seeds or plants produced by conventional propagation methods takes a long time to get new tillers. Therefore, tissue culture techniques can be used to grow and reproduce moon orchid plants. In the success of in vitro culture, the balance of growth regulators is an essential factor. On the other hand, synthetic hormones such as 1-naphthalenaecetic acid (NAA) and 6-benzylaminopurine (BAP) are relatively expensive. The study in this research is to substitute the synthetic hormones NAA and BAP with organic ingredients that are cheap and easy to find. Such as Purple Sweet Potatoes and Beans and find out the right concentration of organic matter. This study used a completely randomized design with two factorials (concentration of purple sweet potato and green beans) with three repetitions. PLB (Protocorm Like Bodies) moon orchid (Phalaenopsis amabilis) was treated with: positive control (2 ppm), negative control (without the addition of organic or synthetic hormones), and variations in the concentration of purple sweet potato and green beans organic matter. The result was that C4D0 $(500 \mathrm{~g} / \mathrm{L}$ purple sweet potato extract and $0 \mathrm{~g} / \mathrm{L}$ green bean extract) was an excellent formulation, although there was no significant interaction between purple sweet potato and green bean extracts against moon orchid.
\end{abstract}

Keywords: Moon Orchid, Organic Ingredients, Beans, Tissue Culture, Purple Sweet Potatoes

\section{INTRODUCTION}

In Indonesia, the agribusiness sector has begun to expand due to the increase in entrepreneurship of orchid plants. Orchids have an immense enough opportunity to succeed in the ornamental plant business because they have a reasonably high market value and guarantee large profits (Dewi, et al., 2015). It is proven that from 2016 to 2018 , the production of ornamental orchid plants continued to increase. In 2016, the production of ornamental orchid plants reached 19,978,078 flower stalks. Then in 2017, it reached 20,045,577 flower stalks, and in 2018 there was an increase to $24,717,840$ orchid flower stalks (BPS, 2018).

Several genera and species of orchid plants are promising to be traded as ornamental plants, one of which is the moon orchid (Phalaenopsis amabilis). Moon orchid plants are generally distributed in the rainforests of southern Indonesia, the Philippines, New Guinea, and Queensland, Australia. P. amabilis can develop into new commercial varieties (Azmi, et al., 2016). There are 25 species of moon orchids in Indonesia, 10 of which are endemic to Indonesia. Therefore, based on the diversity of moon orchid plants that Indonesia has. The moon orchid is one of the ornamental plant commodities with good conservation and economic value with other types of orchids (Rahayu, 2015).

As time goes by, interest in moon orchid plants is increasing. Therefore, efforts are needed to fulfill this demand. Moon orchid plants can be propagated conventionally or modernly. However, the limited number of seeds or plants produced by conventional propagation methods is weak. It takes a long time to get new seedlings. Because orchid seeds do not have an endosperm, conventional seed 
propagation is impossible, so the germination process can only be done through in vitro techniques (Saputri, et al., 2015). Therefore, tissue culture techniques can be used to grow and reproduce moon orchid plants. This technique is very suitable for growing orchid plants in large quantities at once, especially for business in tissue culture.

In the success of in vitro culture, the balance of growth regulators is an essential factor. Growth regulators such as auxins and cytokinins for in vitro culture function and regulate morphogenesis in the formation of shoots and roots in plants. When auxins and cytokinins are administered together, they have a synergistic effect that affects tissue growth (Wattimena, 1992). NAA (Naphthaleneacetic Acid) is a form of synthetic auxin, while BAP (Benzyl Amino Purine) is a synthetic cytokinin (Wattinema, 1988). BAP and NAA hormones are often used in tissue culture processes. However, on the other hand, synthetic hormones such as NAA and BAP have a relatively high price. They are challenging to obtain (Ulfach, 2019).

The solution in this research is to substitute synthetic hormones NAA and BAP with organic ingredients that are cheap and easy to find. Because organic matter can be used as additional material in the media because it has a growth factor regulator that plants need. The organic materials used must contain hormones similar to auxins and cytokinins or have the same or more abilities than synthetic hormones. Some organic materials that are believed to be additives in the media are coconut water, bean sprout extract, tomato extract, betel extract, palm water (Maysarah et al., 2012). Organic materials such as green beans extract contain natural growth factor regulators, namely zeatin, a natural cytokinin (Martin et al., 1999). Furthermore, the content of vitamin B1 (thiamine) similar to auxin in sweet potatoes can stimulate root formation in plants (Untari and Puspitaningtyas, 2006). Therefore, this study used the addition of purple sweet potato extract as a substitute for the NAA hormone and green beans extract as a substitute for the BAP hormone, with different concentrations on the growth of
Phalaenopsis amabilis orchid plantlets to obtain optimal plantlet growth and the suitable formulation of organic hormones.

\section{RESEARCH METHOD}

The research was carried out in the Integrated Laboratory at the Faculty of Health Sciences, Esa Unggul University. North Arjuna Street from June to September 2021. The materials used include MS media (Murashige and Skoog), sugar, bacto agar, BAP and NAA growth regulators, $70 \%$ alcohol, sterile water, orchid plantlets, or PLB lunar orchid in vitro purchased from MyOrchid. The tools used include $\mathrm{pH}$ indicator, magnetic stirrer, autoclave, laminar airflow (LAF), culture bottles, measuring cups, culture racks, glass beakers, Petri dishes, Erlenmeyer flasks, spatulas, tweezers, blades, and scalpels.

\section{Research Procedure}

\section{a) Sterilization of the Planting Room on Laminar Air Flow (LAF) \& Culture Equipment \\ Sterilizes the room and the LAF} table with 96\% alcohol. Next, sterilize culture equipment such as culture bottles, Petri dishes, scalpels, tweezers, and knives. The tools were washed thoroughly with detergent and then dried. After drying, it was wrapped in aluminum foil and then put into an autoclave at a pressure of $1.5 \mathrm{psi}$ $(\mathrm{kg} / \mathrm{cm} 2)$, at a temperature of $120^{\circ} \mathrm{C}$ for 15 minutes.

\section{b) Media Production and Sterilization}

The media used is MS media, added with sugar as a carbon source, and agar from Pytotech mixed with sterile distilled water and extracts of organic materials. After mixing, the $\mathrm{pH}$ was measured from 5.5 to 5.8. After the $\mathrm{pH}$ is appropriate, then heat the medium until it dissolves completely. Then pour into culture bottles with the same volume in each bottle and close it. The culture media sterilized in an autoclave at a pressure of $1.5 \mathrm{psi}(\mathrm{kg} / \mathrm{cm} 2)$, at a temperature of $120^{\circ} \mathrm{C}$ for 15 minutes 


\section{c) Addition of Organic Ingredients Extract}

This study uses a combination of treatments is $5 \times 5=25$ combinations, with a completely randomized design with two factorial with three repetitions:

\begin{tabular}{|l|l|l|l|l|l|l|l|l|l|l|l|l|}
\hline $\mathrm{C}$ & $\mathrm{C}$ & $\mathrm{C}$ & $\mathrm{C}$ & $\mathrm{C}$ & $\mathrm{C}$ & $\mathrm{C}$ & $\mathrm{C}$ & $\mathrm{C}$ & $\mathrm{C}$ & $\mathrm{C}$ & $\mathrm{C}$ & $\mathrm{C}$ \\
0 & 1 & 2 & 3 & 4 & 0 & 1 & 2 & 3 & 4 & 0 & 1 & 2 \\
$\mathrm{D}$ & $\mathrm{D}$ & $\mathrm{D}$ & $\mathrm{D}$ & $\mathrm{D}$ & $\mathrm{D}$ & $\mathrm{D}$ & $\mathrm{D}$ & $\mathrm{D}$ & $\mathrm{D}$ & $\mathrm{D}$ & $\mathrm{D}$ & $\mathrm{D}$ \\
0 & 0 & 0 & 0 & 0 & 1 & 1 & 1 & 1 & 1 & 2 & 2 & 2 \\
\hline $\mathrm{C}$ & $\mathrm{C}$ & $\mathrm{C}$ & $\mathrm{C}$ & $\mathrm{C}$ & $\mathrm{C}$ & $\mathrm{C}$ & $\mathrm{C}$ & $\mathrm{C}$ & $\mathrm{C}$ & $\mathrm{C}$ & $\mathrm{C}$ & \\
3 & 4 & 0 & 1 & 2 & 3 & 4 & 0 & 1 & 2 & 3 & 4 & \\
$\mathrm{D}$ & $\mathrm{D}$ & $\mathrm{D}$ & $\mathrm{D}$ & $\mathrm{D}$ & $\mathrm{D}$ & $\mathrm{D}$ & $\mathrm{D}$ & $\mathrm{D}$ & $\mathrm{D}$ & $\mathrm{D}$ & $\mathrm{D}$ & \\
2 & 2 & 3 & 3 & 3 & 3 & 3 & 4 & 4 & 4 & 4 & 4 & \\
\hline
\end{tabular}

Each treatment was carried out three times with 75 culture bottles with one orchid plantlet per bottle.

- Positive control: BAP 2 ppm

- Negative control: Without the addition of synthetic hormones

- The first factor is the addition of purple sweet potato extract treatment at five levels: (1) C0: without extract (Control), (2) $\mathrm{C} 1: 200 \mathrm{~g} / \mathrm{L}$, (3) C2: $300 \mathrm{~g} / \mathrm{L}$, (4) C3: $400 \mathrm{~g} / \mathrm{L},(5) \mathrm{C} 4: 500 \mathrm{~g} / \mathrm{L}$

- The second factor is the addition of green bean extract treatment at five levels: (1) D0: without green bean extract (Control), (2) D1: $200 \mathrm{~g} / \mathrm{L}$, (3) D2: $300 \mathrm{~g} / \mathrm{L}$, (4) D3: $400 \mathrm{~g} / \mathrm{L}$, (5) D4; $500 \mathrm{~g} / \mathrm{L}$.

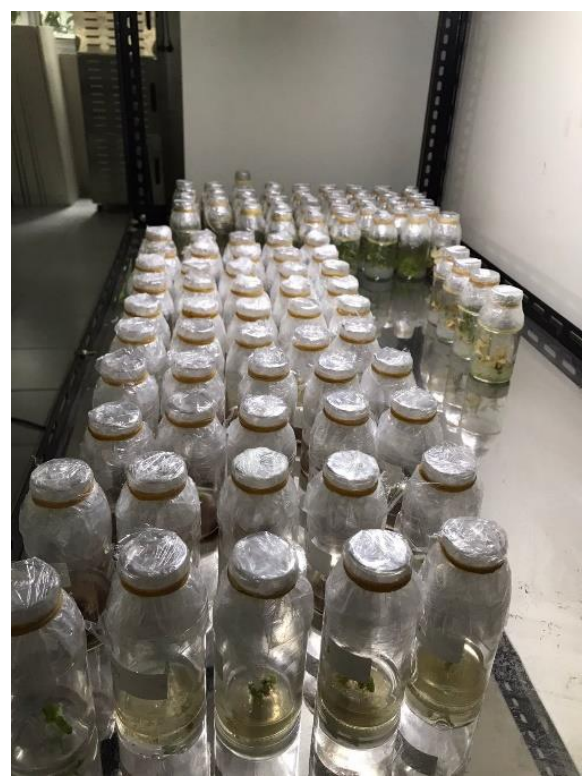

Figure 1. Result of Subculture

\section{d) In Vitro Culture Planting}

The explant used was an in vitro culture of moon orchid obtained from Esha Flora. The explants were then subcultured into media containing purple sweet potato and green bean extract in LAF.

\section{e) Maintenance in the Culture Room and Plantlet Measurement Based on Parameters}

Sterilization was carried out by spraying alcohol every week to reduce the source of contamination in the culture room. Contaminated bottles are immediately removed from the culture room. The culture room temperature was maintained consistently at $23^{\circ} \mathrm{C}$. The parameters tested were leaf length, plantlet height, and root length after one month. ANOVA was then analyzed to see the best concentration of organic matter in optimal orchid growth.

\section{f) Data Analysis, Interpretation and Conclusions of Research Results}

The research data were analyzed quantitatively (measurement based on the tested parameters). Then it was analyzed using Analysis of Variance (ANOVA) and continued with Duncan's mean difference test (DMRT at 5\% level) if the result was significant. Interpreting the data was by comparing the growth results of moon orchid plantlets treated with synthetic hormones (NAA and BAP) and those given other ingredients. Organic matter (purple sweet potato extract and green bean extract). Meanwhile, the research conclusion is based on comparing the results of the parameters tested, where the administration of $2 \mathrm{ppm}$ BAP has a significant effect on moon orchids in the initial culture that can grow Phalaenopsis amabilis orchid plantlet. So, it can be said that the activity of organic matter growth factor regulation is equivalent to expensive synthetic hormones.

\section{RESULT AND DISCUSSION}

The tissue culture method was created to help propagate plants, especially orchids, which do not have endosperm and food reserves. They are challenging to multiplication. Orchid tissue culture has the advantage of producing large quantities of 
orchid seeds quickly. The correct media and growth regulators are used during morphogenesis and organogenesis, then can cell division activity will increase (Lestari, 2011).

There were 25 variations in the concentration of purple sweet potato and green beans organic matter in this study with three repetitions and one positive control variation. The total number of subcultures made was 76 culture bottles, with each bottle containing one plantlet. After the media is made and sterilized using an autoclave, the media is left at room temperature for at least one week to see whether or not the growth of microorganisms occurs in the media. If not, the media made is completely sterile and ready to be used for subculture. Because the media made was coated with plastic and rubberized tightly after being autoclaved at temperature of $120^{\circ} \mathrm{C}$ for 15 minutes.

In subculture tissue culture, it is necessary to obtain a high and large number of plants by transferring the culture to a new medium to increase growth and meet nutritional needs. If many shoots and shoots are formed, they are separated and planted in new media to ensure that the nutritional needs of the explant medium are met, and the explants can create new organs or structures
(Rodinah, et al., 2018). The subcultures that we did not any contamination after being observed for a week. If contamination occurs, mold will grow on the surface layer of the media in the bottle, but our subculture was successful because it was free from contamination. Contamination is very susceptible to not aseptic treatment in Laminar Air Flow, such as forgetting to burn the knife on the bunsen, not sterilizing the handscoon, and not tightly closing the culture bottle after the subculture process. Media contamination can also occur due to not tightly closing the culture bottle so that spores or microorganisms can enter and grow through the nutrients present in the media.

Based on the average calculation with Ms. Excell in table 1, the best growth in leaf length and root length was C4D0 $(500 \mathrm{~g} / \mathrm{L}$ purple sweet potato extract and 0 $\mathrm{g} / \mathrm{L}$ green beans extract). Meanwhile, the plantlet height parameter was coded for C3DO $(400 \mathrm{~g} / \mathrm{L}$ purple sweet potato extract and $0 \mathrm{~g} / \mathrm{L}$ green beans extract). Then in table 2 . The combination of synthetic hormones did not significantly affect it because it was only observed 25 days after the subculture, which should have been observed for 3-4 months.
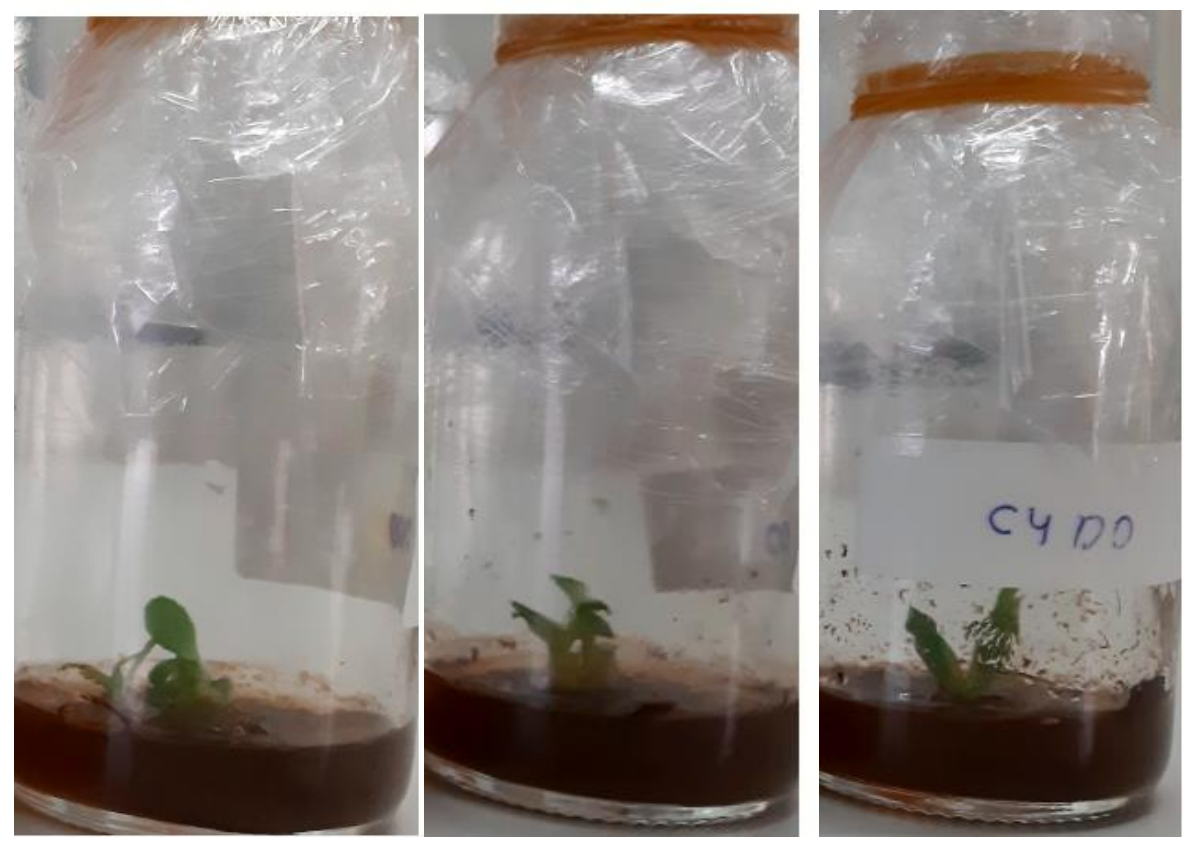

Figure 2. Day 1 (C4D0) 

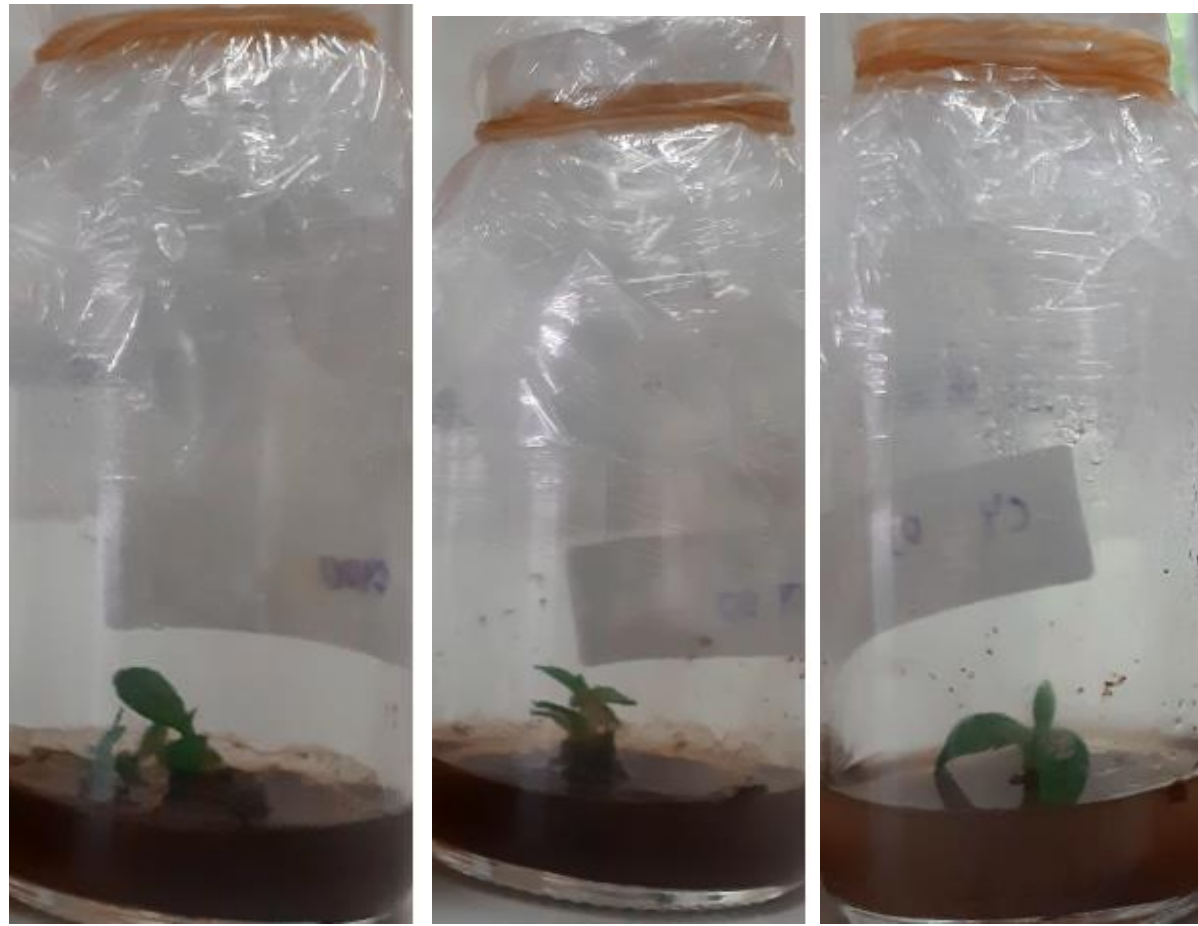

Figure 3. Day 25 (C4D0)

Table. 1 Average Growth of Moon Orchid Explants on Addition of Organic Materials

\begin{tabular}{|l|l|l|l|}
\hline Experiment & Plantlet height $(\mathrm{cm})$ & Root length $(\mathrm{cm})$ & Leaf length $(\mathrm{cm})$ \\
\hline C0D0 & 0,933333333 & 0 & 0,966666667 \\
\hline C0D1 & 1 & 0,166666667 & 0,676666667 \\
\hline C0D2 & 0,4 & 0,166666667 & 0,4 \\
\hline C0D3 & 0,8 & 0,666666667 & 0,583333333 \\
\hline C0D4 & 1 & 0,266666667 & 0,875 \\
\hline C1D0 & 1 & 0 & 0,666666667 \\
\hline C1D1 & 1 & 0,166666667 & 0,533333333 \\
\hline C1D2 & 0,666666667 & 0 & 0,533333333 \\
\hline C1D3 & 0,6 & 0,066666667 & 0,45 \\
\hline C1D4 & 1 & 0 & 0,9 \\
\hline C2D0 & 0,833333333 & 0 & 0,783333333 \\
\hline C2D1 & 0,833333333 & 0,266666667 & 0,75 \\
\hline C2D2 & 0,266666667 & 0 & 0,266666667 \\
\hline C2D3 & 0,633333333 & 0,333333333 & 0,5 \\
\hline C2D4 & 0,833333333 & 0,4 & 0,686666667 \\
\hline C3D0 & 1,066666667 & 0,433333333 & 0,966666667 \\
\hline C3D1 & 0,633333333 & 0,333333333 & 0,7 \\
\hline C3D2 & 0,733333333 & 0,266666667 & 1 \\
\hline C3D3 & 0,833333333 & 0,4 & 0,666666667 \\
\hline C3D4 & 1,033333333 & 0,233333333 & 1,066666667 \\
\hline C4D0 & 0,866666667 & 0,266666667 & 1,1 \\
\hline C4D1 & 0,933333333 & 0,266666667 & 0,753333333 \\
\hline C4D2 & 0,933333333 & 0,266666667 & 0,933333333 \\
\hline C4D3 & 0,8 & 0,166666667 & 1 \\
\hline C4D4 & 1 & 0,233333333 & 0,833333333 \\
\hline & & & \\
\hline
\end{tabular}


Table. 2 Growth Results of Moon Orchid Plants with Synthetic Hormones

\begin{tabular}{|l|l|l|l|}
\hline Experiment & Plantlet height $(\mathrm{cm})$ & Root length $(\mathrm{cm})$ & Leaf length $(\mathrm{cm}$ \\
\hline 2 ppm NAA & 0,8 & 0 & 1 \\
\hline 2 ppm BAP & 0,5 & 0 & 1 \\
\hline $\begin{array}{l}2 \text { ppm NAA }+ \\
2 \text { ppm BAP }\end{array}$ & 0,5 & 0 & 1 \\
\hline
\end{tabular}

Table. 3. Results of ANOVA on the Addition with Organic Materials

\begin{tabular}{|c|c|c|c|c|c|c|}
\hline Source of Variation & SS & $d f$ & $M S$ & $F$ & $P$-value & $F$ crit \\
\hline Sample & 4,80518889 & 24 & 0,2002162 & 1,328350395 & 0,154812562 & 1,590188252 \\
\hline Columns & 16,5782722 & 2 & 8,28913611 & 54,9949356 & $1,22 \mathrm{E}-18$ & 3,056366295 \\
\hline Interaction & 3,76277778 & 48 & 0,0783912 & 0,520092702 & 0,995019317 & 1,442463847 \\
\hline Within & 22,6088167 & 150 & 0,15072544 & & & \\
\hline Total & 47,7550556 & 224 & & & & \\
\hline
\end{tabular}

From the research carried out, it can be said that there is an influence between organic matter and synthetic hormones on moon orchids and synthetic hormones with organic materials that have values that are not too much different. Based on the data obtained in ANOVA Two Factors with replication on Ms. Excell showed that there was a significant difference in the parameter categories, namely plantlet height, root length, and leaf length, which could be seen in the P-Value sample of 0.154812562 where the value was $<0.05$, then there was no significant difference in the formulation category. It can be seen in the P-Value columns that are greater than 0.05 . Furthermore, the ANOVA data showed that there was no significant interaction in the organic matter formulation aimed at a PValue value of 0.99 , which was greater than 0.05 .

This happened due to the short observations that did not reach a month so that the plantlets had not been said to grow optimally, but it can be said that the C4D0 formulation was the best formulation so far for the growth of moon orchids.

\section{CONCLUSION}

There was an effect of adding organic matter and synthetic hormones to the growth of lunar orchids, but there was no significant difference in the addition of organic matter and synthetic hormones to the growth of lunar orchids due to too short observations. There was no significant interaction between the addition of purple sweet potato extract and green beans to the media for the growth of moon orchids, but the best combination was obtained on the C4D0 label $(400 \mathrm{~g} / \mathrm{L}$ purple sweet potato extract and $0 \mathrm{~g} / \mathrm{L}$ green beans) for the growth of lunar orchids.

\section{ACKNOWLEDGEMENT}

We want to thank the Ministry of Education, Culture, Research, and Technology and the Directorate of Learning and Student Affairs for the grants given for this research.

\section{REFERENCES}

Azmi, T.K., Sukma, D., Aziz, S.A. and Syukur, M., 2016. Polyploidy induction of moth orchid (Phalaenopsis amabilis (L.) Blume) by colchicine treatment on pollinated flowers. The Journal of Agricultural Sciences. 11(2): $62-73$.

Badan Pusat Statistik. 2018. Produksi Tanaman Florikultura (Hias) 2018. URL:

https://www.bps.go.id/indicator/55/6 4/2/produksi-tanaman-florikulturahias-.html. Retrieved March 92021.

Baday, S.J., 2019. Plant Tissue Culture. International. J. Agriculture and Environmental Research. 4(4): 977-990

Bey, Y., Syafii, W. dan Sutrisna. 2006. Pengaruh Pemberian Giberelin (GA3) Dan Air Kelapa Terhadap Perkecambahan Bahan Biji Anggrek Bulan (Phalaenopsis Amabilis L) 
Secara In Vitro. Biogenesis. 2(2):4146.

Dewi, I. A. L., Suamba, I. K. dan Wati, K. W. C. 2015. Kinerja Usaha Tanaman Anggrek Bulan (Phalaenopsis amabilis) pada PT Multi Agro Bali di Desa Sembung Kecamatan Mengwi Kabupaten Badung. Journal of Agribusiness and Agritourism. 4(1): 37-46.

Hartati, S., Budiyono, A. dan Cahyono, O. 2016. Pengaruh NAA dan BAP terhadap pertumbuhan subkultur anggrek hasil persilangan Dendrobium biggibum X Dendrobium liniale. Caraka Tani: Journal of Sustainable Agriculture, 31(1):33-37. DOI:

10.20961/carakatani.v31i1.11938.

Karjadi, A.K. dan Buchory, A. 2008. Pengaruh Auksin dan Sitokinin Terhadap Pertumbuhan dan Perkembangan Jaringan Meristem Kentang Kultivar Granola. $J$. Hortikultura. 18(4):380-384. DOI: 10.21082/jhort.v18n4.2008.p

Kende, H. and Zeevaart, J. 1997. The five" Classical" plant hormones. The plant cell. 9(7):1197.

Kurniasih, S dan Munarti. 2015 .Perbandingan Kandungan Mineral Dan Vitamin B1 Beberapa Jenis Ubi Jalar (Ipomoea batatas L.). SEMIRATA 2015, 4(1):200-206.

Martin, R. C., Mok, M. C. and Mok, D. W. S. 1999. A gene encoding the cytokinin enzyme zeatin Oxylosyltransferase of Phaseolus vulgaris. Plant Physiology. 120(2); 553-557.

DOI:

10.1104/pp.120.2.553.

Maysarah, W., Reine S. dan Herlina, D. 2012. Pertumbuhan Eksplan Manggis (Garcinia mangostana L.) Secara In Vitro Dengan Air Kelapa, Ekstrak Tauge Dan Ragi. Jurnal Hutan Lestari. 1(1): 9-15.

Nikolelis, D.P., Chaloulakos, T.I., Nikoleli, G.P. dan Psaroudakis, N. 2008. A portable sensor for the rapid detection of naphthalene acetic acid in fruits and vegetables using stabilized in air lipid films with incorporated auxin-binding protein 1 receptor. Talanta. 77(2): 786-792.

Rahayu, E.M.D. 2015. Conservation of moth orchids (Phalaenopsis spp.) in Center for Plant Conservation Botanic Gardens-LIPI, Bogor. In Prosiding Seminar Nasional Masyarakat Biodiversitas Indonesia. 8 Desember 2015. 1(8):1847-1850. DOI: $10.13057 / \mathrm{psnmbi} / \mathrm{m} 010816$.

Rodinah, R., Hardarani, N., \& Ariani, H. D. 2018. Modifikasi Media dan Periode Subkultur pada Kultur Jaringan Pisang Talas (Musa Paradisiaca Var. Sapientum L.). Jurnal Hexagro, 2(2), 292605.

Rukmana, H. R. 2008. Budi Daya Anggrek Bulan. Penerbit Kanisius. Yogyakarta.

Saputri, W., Mukarlina dan Linda, R. 2015. Respon Pertumbuhan Anggrek Hitam (Coelogyne pandurata Lindl.) Secara In-Vitro dengan Penambahan Ekstrak Taoge dan Benzyl Amino Purine (BAP). Protobiont. 4(2):84-89.

Tang CY, Chen WH. 2007. Breeding and development of new varieties in Phalaenopsis. In: Chen WH, Chen HH (eds) Orchids Biotechnology.World Scientific, New Jersey. pp 1-22

Ulfa, F., Sengin, E.L., Baharuddin, B., Syaiful, S.A., Sennang, N.R., Rafiuddin, R., Nurfaida, N. and Ifayanti, I., 2015. Potential of plant extracts as growth exogenous regulators of potato seeds. International Journal of Agriculture System. 1(2): 98-103.

Ulfach, M. 2019. Kombinasi Pemberian Ekstrak Tauge Dan Air Kelapa Pada Media Ms (Murashige Dan Skoog) Terhadap Pertumbuhan Planlet Kentang (Solanum tuberosum L.) Secara In Vitro. Skripsi. Fakultas Pertanian Universitas Muhammadiyah Sumatera Utara Medan.

Untari, R. and Puspitaningtyas, D. M. (2006). The effect of some organic compounds and NAA application on the in vitro growth of the black orchid (Coelogyne pandurata Lindl.). Biodiversitas Journal of Biological 
Diversity. $\quad 7(4): 344-348 . \quad$ DOI: 10.13057/biodiv/d070409.

Wattimena, G.A., 1988. Zat pengatur tumbuh tanaman. Pusat Antar Universitas Institut Pertanian Bogor Bekerjasama Deengan Lembaga Sumberdaya Informasi-IPB, pp.1145.

Wattimena, GA. 1992. Bioteknologi tanaman I. Departement Pendidikan dan Kebudayaan Direktoral Jendral pendidikan Tinggi Pusat Antar Universitas Bioteknologi. Institut Pertanian Bogor. Bogor

Yuswanti, H., Dharma, I.P., Utami, U. dan Wiraatmaja, $\quad$ I.W. 2015. Mikropropagasi Anggrek Phalaenopsis dengan Menggunakan Eksplan Tangkai Bunga. Agrotrop: Journal on Agriculture Science, 5(2):163-168. 